\title{
EVOLUÇÃO DO ENSINO DA CONTABILIDADE NO BRASIL: UMA ANÁLISE HISTÓRICA ${ }^{1}$
}

\section{EVOLUTION OF THE ACCOUNTING EDUCATION IN BRAZIL: A HISTORICAL ANALYSIS}

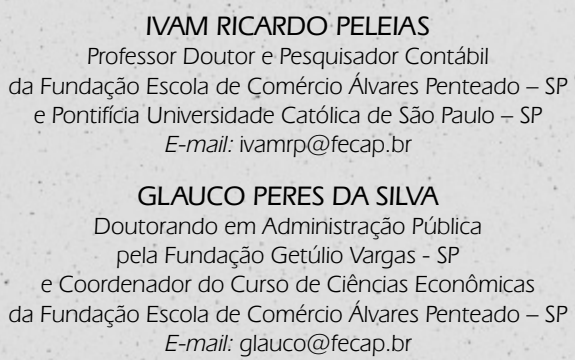

IVAM RICARDO PELEIAS

Professor Doutor e Pesquisador Contábil

da Fundação Escola de Comércio Álvares Penteado - SP

e Pontifícia Universidade Católica de São Paulo - SP

E-mail: ivamrp@fecap.br

GLAUCO PERES DA SILVA

Doutorando em Administração Pública

pela Fundação Getúlio Vargas - SP

e Coordenador do Curso de Ciências Econômicas

da Fundação Escola de Comércio Álvares Penteado - SP E-mail: glauco@fecap.br

\author{
JOÃO BOSCO SEGRETI \\ Professor Doutor e Pesquisador Contábil \\ da Fundação Escola de Comércio Álvares Penteado - SP \\ E-mail:segreti@fecap.br \\ AMANDA RUSSO CHIROTTO \\ Pesquisadora Contábil \\ da Fundação Escola de Comércio Álvares Penteado - SP \\ E-mail: amanda.chirotto@fecap.br
}

\section{RESUMO}

A pesquisa histórica permite identificar, resgatar e analisar marcos relevantes da evolução da sociedade, no mundo e no Brasil. Um marco importante é o impacto das ocorrências econômicas, políticas e sociais no ensino, pois tais mudanças demandam profissionais mais bem preparados. Em função do exposto, este trabalho apresenta o resultado de pesquisa realizada nas áreas de Contabilidade e Economia, sobre a evolução do ensino de Contabilidade no Brasil, e o impacto que alguns eventos econômicos, políticos e sociais tiveram nessa evolução. A pesquisa é histórica, documental, bibliográfica e descritiva. Foi analisada a legislação nacional sobre o ensino comercial e contábil promulgada no Brasil, do século XIX até os dias atuais. Foram identificadas ocorrências relevantes no cenário nacional, a partir da chegada da Família Real, em 1808, e os efeitos que esse fato e outros que se sucederam tiveram sobre a regulamentação do ensino da Contabilidade no Brasil. Os resultados obtidos permitiram identificar como algumas ocorrências econômicas, políticas e sociais afetaram o ensino contábil e a forma como a legislação analisada evoluiu até os dias atuais.

Palavras-chave: Ensino da Contabilidade; Evolução Histórica; Ensino Comercial; Ensino Técnico e Profissionalizante; História da Contabilidade.

\section{ABSTRACT}

The historical research allows to identify, to rescue and to analyze relevant landmarks of the evolution of the society, in the world and Brazil. An important landmark is the impact of the economic, social and politic occurrences on education, therefore such changes demand most prepared professionals. In function of the displayed one, this work presents the result of research carried through in the areas of Accounting and Economy, on the evolution of the Accounting Education in Brazil, and the impact that some economic, social and politic events had on this evolution. This is a historical, documentary, bibliographical and descriptive research. It was analyzed the nationwide legislation on commercial and Accounting Education in Brazil, from the nineteenth century until the current days. Relevant occurrences in the national scene from the arrival of the Real Family in 1808 had been identified, and the effect that this fact and others that had occurred had on the regulation of the Accounting education in Brazil. The gotten results had allowed to identify as some economic, social and politic occurrences had affected the Accounting education, and the form as the analyzed legislation evolved until the current days.

Keywords: Accounting Education; Historical Evolution; Commercial Education; Technician and Professional Education, Accounting History. 


\section{INTRODUÇÃO}

A evolução das sociedades apresenta características que demandam identificação, estudo e compreensão, e o progresso econômico requer profissionais mais qualificados para atuarem nas organizações. Como conseqüência, são necessárias condições de ensino para a formação desses profissionais. Tais acontecimentos colaboram para o desenvolvimento político e social, pois esses profissionais poderão se tornar cidadãos mais cônscios de seus direitos e deveres. O estudo desse processo evolutivo requer a realização da pesquisa histórica.

A pesquisa histórica (LUNA, 2002, p.86-88) permite recuperar a evolução de conceitos, temas e áreas, e a inserção dessa evolução em um quadro referencial que ajude a explicar os fatores determinantes e as implicações das mudanças ocorridas. Requer a obtenção de fontes primárias de pesquisa, e contribui para confirmar, integrar, complementar ou mesmo corrigir aspectos históricos tratados em outros trabalhos já realizados.

Este artigo relata o resultado de pesquisa interdisciplinar, nas áreas de Contabilidade e de Economia, que analisou a legislação nacional sobre o ensino comercial e de Contabilidade promulgada no Brasil. A análise teve como referenciais eventos econômicos, políticos e sociais importantes, ocorridos a partir da chegada da Família Real ao Brasil, em 1808, estudados por pesquisadores contábeis e econômicos.

O estudo combinou a pesquisa histórica (LUNA, 2002) por abranger o início do século XIX até os dias atuais; descritiva (APPOLINÁRIO, 2004, p.153), por requerer análise detalhada sobre a legislação do ensino comercial e contábil; documental (APPOLINÁRIO, op. cit.), pois os elementos relativos às mudanças no ensino comercial e de Contabilidade foram obtidos na referida legislação e bibliográfica (APPOLINÁRIO, op. cit., p. 152). Foram consultadas obras de Economia Brasileira, para identificar eventos importantes havidos no período coberto, e de Contabilidade, para identificar elementos históricos que revelam como a Contabilidade tem respondido às demandas da sociedade, analisados por estudiosos e pesquisadores contábeis.

Sobre a pós-graduação em Contabilidade, as fontes consultadas foram: a legislação pesquisada, os sites das instituições mantenedoras dos programas Stricto Sensu, da CAPES - Coordenação de Aperfeiçoamento de Pessoal de Nível Superior, informações telefônicas colhidas junto às secretarias dos programas e o estatuto de criação da ANPCONT - Associação Nacional de Programas de Pós-Graduação em Ciências Contábeis.

A escolha da chegada da Família Real ao Brasil, como ponto de partida, ocorreu por ser um marco histórico relevante, destacada por pesquisadores das áreas de Contabilidade (SCHMIDT, 2000) e de Economia (PRADO JR., 1998). Esse fato teve repercussão política, pois culminou na independência do País, em 1822. Causou, também, impacto econômico, pois tornou o Brasil o centro decisório da movimentação de recursos do Império Português, e social, pelas mudanças que a partir daí ocorreram na sociedade brasileira.

\section{A EVOLUÇÃO DA CONTABILIDADE E SUA RELAÇÃO COM A EVOLUÇÃO DA SOCIEDADE}

A evolução da Contabilidade está associada ao progresso da humanidade. Esse fato é identificado e analisado sob distintas perspectivas. A opinião de alguns pensadores, e os aspectos por eles identificados, são, a seguir, apresentados.

Melis (1950, p.3) destacou que a Contabilidade e sua principal e mais característica manifestação - a conta - é tão antiga quanto a civilização construída pelos homens. Dessa forma, a história da Contabilidade é, em certo ponto, uma conseqüência da história da civilização, de suas vicissitudes às mais altas manifestações, sobretudo no campo econômico.

Vlaemminck (1961) analisou a evolução histórica da Contabilidade e estabeleceu a correlação de sua evolução com a Economia. Apresentou a Contabilidade como técnica auxiliar da Economia, que aparece, se expande, se degenera ou se retrai ao compasso da evolução econômica das civilizações, nas diversas regiões e distintas épocas de sua história. Ressaltou, ainda, o paralelismo entre a evolução econômica geral e a evolução de um dos métodos contábeis a serviço da economia das empresas: a técnica das contas. ludícibus (2006, p.35) cita que, em termos de compreensão da evolução histórica contábil, raramente o "estado da arte" ultrapassa o grau de evolução econômica, institucional e social das sociedades analisadas, em cada época. Para o autor, a produção das teorias contábeis e de suas práticas está associada, na maioria das vezes, ao grau de evolução comercial, social e institucional das sociedades, cidades ou nações.

Sá (1997, p.16) lembra que a Contabilidade nasceu com a civilização e jamais deixará de existir em decorrência dela; talvez, por isso, quase sempre seus progressos coincidiram com aqueles que caracterizam os da evolução do homem.

Schmidt (2000, p.12) assevera que a Contabilidade se manifestou antes do homem desenvolver a civilidade. Assim como o homem progrediu, também a Contabilidade, necessária ao progresso da humanidade, perseguiu essa evolução. Para o autor (op. cit.), isso revela que, como outros ramos do conhecimento ligados à sociedade, a História do Pensamento Contábil é produto do meio social de seus usuários, em termos de espaço e de tempo. 


\begin{tabular}{|l|l|l|}
\hline Entidade & País & Site \\
The Academy of Accounting Historians & Estados Unidos & accounting.rutgers.edu/raw/aah/ \\
\hline Societá Italiana de Storia de la Ragioneria & Itália & www.sisronline.it \\
\hline Associação Portuguesa dos Técnicos de Contabilidade & Portugal & www.apotec.pt \\
\hline AECA - Comissión de Historia de la Contabilidad & Espanha & www.aeca.org \\
\hline AFAANZ - Accounting History Special Group & Austrália e Nova Zelândia & www.afaanz.org \\
\hline
\end{tabular}

Fonte: sites das entidades

Quadro 1 Algumas entidades dedicadas ao estudo e à pesquisa histórica contábil

\begin{tabular}{|l|l|}
\hline Entidade & Publicação \\
\hline $\begin{array}{l}\text { APOTEC - Associação Portuguesa dos Técnicos } \\
\text { de Contabilidade - Portugal }\end{array}$ & Boletim do Centro de Estudos de História da Contabilidade \\
\hline $\begin{array}{l}\text { Academy of Accounting Historians - Estados } \\
\text { Unidos }\end{array}$ & Accounting Historians Journal \\
\hline Routldege Inc., Reino Unido & Accounting, Business \& Financial History \\
\hline
\end{tabular}

Fonte: Revista Apotec e Base de dados EBSCO - consulta em 25.06.2006

Quadro 2 Entidades e publicações sobre História da Contabilidade

A importância da pesquisa histórica contábil verifica-se pelo surgimento de entidades a ela dedicadas, conforme se vê no Quadro 10.

Essas entidades promovem eventos internacionais, em que são aceitos e debatidos trabalhos sobre a História da
Contabilidade. Também é possível identificar periódicos voltados à publicação de tais trabalhos, conforme se verifica no Quadro $2 \mathbf{0}$.

\section{A PESOUISA HISTÓRICA EM CONTABILIDADE NO BRASIL}

O interesse pela pesquisa histórica contábil existe no País, motivado por dois fatores: o aumento do número de programas Stricto Sensu em Controladoria e Contabilidade, principalmente a partir da Lei $n^{\circ}$ 9394/96, e o advento das novas diretrizes curriculares nacionais para os cursos de Ciências Contábeis, com o Parecer CNE/CES nº. 289/2003, e da Resolução CNE/CES no. 10/2004, que propugnam a formação de profissionais dotados de competências profissionais que reflitam a heterogeneidade das demandas sociais.

Antes do movimento citado no parágrafo anterior, destacam-se dois estudos sobre o ensino comercial e da Contabilidade no Brasil. O primeiro, realizado por Rodigues (1984), a partir de pesquisas realizadas no Arquivo Geral da Marinha do Brasil e Arquivo Nacional, é uma cronologia de ocorrências sobre o ensino comercial e da Contabilidade no Brasil. O trabalho principia informando a iniciativa de criação da Academia Militar, Náutica e Econômica que, se concretizada, seria a primeira universidade brasileira, e também a primeira Faculdade de Economia do mundo, e finda informando a extinção formal do Instituto Comercial do Rio de Janeiro, via Decreto no. 832, de 07 de maio de 1902.

O segundo, de Lawrence (1962), descreveu a experiência do autor como professor visitante na Escola de Administração de Empresas da Fundação Getúlio Vargas. O autor apresentou uma pequena cronologia de leis sobre o ensino comercial e contábil do Brasil no século XX, e a maior parte da pesquisa tratou de suas constatações $e$ conclusões sobre as condições do ensino noturno de Contabilidade no Brasil.

Um aspecto perceptível nos trabalhos históricos desenvolvidos a partir do século XXI é a importância do ensino e de suas condições de oferta, para atender à crescente demanda por profissionais mais qualificados, para atuar numa economia que, ao longo do século XIX ensaiou seus primeiros passos e, desde o século $\mathrm{XX}$, busca sua consolidação.

Saes e Cytrynowicz (2001, p.37-59) analisaram como o ensino comercial contribuiu para a origem dos cursos superiores de Economia, Administração e Contabilidade no País. Tomaram a criação da Aula de Comércio por D. João $\mathrm{VI}$, em 1808, como marco de pesquisa, e estenderam a análise até a criação de tais cursos superiores. Apontaram que, para o ensino comercial identificado com a formação do contador, havia um aprendizado formal de técnicas de gestão dos negócios e que os três cursos eram um desdobramento do ensino comercial. Concluíram sua pesquisa evidenciando que a distinção entre os cursos é recente $e$ muitas funções exercidas por tais profissionais possuem sobreposições até os dias atuais. 
Bacci (2002) estudou a evolução da Contabilidade no Brasil, enfatizando a influência da legislação na profissão contábil, os esforços para o reconhecimento da profissão e para a criação dos órgãos de classe. Apontou como conseqüências da legislação sobre a profissão a padronização das demonstrações contábeis, a necessidade da fiscalização do exercício da profissão pelos órgãos de classe e a criação no século XX dos cursos técnicos, profissionalizantes e superiores.

Ricardino Filho (2002) analisou em que extensão os conteúdos dos livros texto de auditoria, usados por professores brasileiros atendem aos requisitos mínimos sugeridos pelo ISAR-ONU para a formação de contadores globais. O trabalho apontou o $1^{\circ}$. livro de auditoria publicado no Brasil, em 1957, e detectou que os aprendizes recrutados pelas empresas de auditoria atuantes no Brasil recebem treinamento dos contratantes, mesmo tendo estudado auditoria nos cursos superiores. $\mathrm{O}$ autor apontou, como razão da duplicação de esforços, as diferenças substanciais de objetivos em tais cursos e as distintas orientações adotadas pelas faculdades e empresas de auditoria, o que leva a adoção de diferentes conteúdos.

Ricardino Filho realizou outras pesquisas históricas contábeis em conjunto com outros pesquisadores (IUDíCIBUS, RICARDINO FILHO, 2002; RICARDINO FILHO E MARTINS, 2003; RICARDINO FILHO E MARTINS, 2004). Além desses, realizou trabalho em conjunto com Martins et al. (2006), indicando que, na Escola Politécnica, possivelmente teria ocorrido o primeiro curso formal de Contabilidade do Estado de São Paulo. Este trabalho recebeu o seguinte comentário de ludícibus (2006, p.41):

Provavelmente a primeira escola especializada no ensino da Contabilidade foi a Escola de Comércio Álvares Penteado, criada em 1902. Alguns autores preferem fazer recair a honra do pioneirismo na Escola Politécnica de São Paulo, a qual, alguns anos antes, em seu Curso Preliminar, já incluía a disciplina Escrituração Mercantil. Conquanto legalmente e cronologicamente tais autores possam ter razão, o fato de haver a disciplina de Escrituração Mercantil não caracteriza, a meu ver, um Curso de Contabilidade.

Coliath (2003) propôs um modelo de conteúdo programático para o ensino de História do Pensamento Contábil nos cursos de Ciências Contábeis. Justificou seu trabalho asseverando o interesse da pesquisa histórica nos cursos de Administração e de Economia e que o estudo da evolução do pensamento contábil ajuda a compreender os alicerces que fundamentam a pesquisa contábil, e que a disciplina poderia aumentar a cultura geral dos futuros contadores. Em sua proposta, reservou parte substancial para o estudo da História da Contabilidade no Brasil.

Ericeira (2003) estudou o estado da arte da Contabilidade no Estado do Maranhão, vis-à-vis sua evolução, entre 1755 e 1900, e identificou dois momentos relativos às Aulas de Comércio. O primeiro, na $2^{\mathrm{a}}$. metade do século XVIII, no qual a situação econômica, política e social da então Colônia não permitia o ensino e o estudo das práticas comerciais. O segundo, na $1^{\text {a }}$. metade do século XIX, no qual houve a instalação da primeira aula de comércio no Maranhão em 1811.

Leite (2005) pesquisou a evolução do ensino da Contabilidade no Brasil, cujo pano de fundo a situação econômica e social, e seus reflexos na educação. $O$ autor (op. cit., p.49-53) observou que o ensino médio literário era considerado mais importante do que o comercial profissionalizante, pois a classe dominante entendia que tal ensino era reservado às camadas inferiores da população. $\mathrm{O}$ mesmo sentimento identificado no ensino médio ocorria no superior, pois havia apenas os cursos de Direito, Engenharia e Medicina. Vem, dessa época, o baixo interesse pelo ensino comercial em relação a outras opções para a formação profissional. Relatou que tal situação começaria a mudar a partir do final do século XIX, com a chegada dos primeiros imigrantes, o crescimento econômico e a necessidade de profissionais brasileiros mais qualificados, o que demandou o aumento da oferta do ensino comercial no Brasil.

Silva (2005) realizou recorte temporal no século XIX, no qual pesquisou e analisou as leis, o ensino e a literatura contábil. Justificou seu trabalho pela pouca exploração da História da Contabilidade, pois os estudos, até então realizados, se limitavam a alguns fatos pontuais e isolados. Identificou lacunas e a necessidade de melhor identificar e especificar constatações relatadas por outros pesquisadores, como, por exemplo, a efetiva data e condições de ocorrência da $1^{\mathrm{a}}$. aula de comércio. Esse trabalho objetivou oferecer um quadro mais completo e ilustrado sobre o ensino comercial e de Contabilidade no século XIX, além de complementar e corrigir outras pesquisas já realizadas.

Identificados os aspectos históricos relativos ao ensino da Contabilidade nos trabalhos analisados, a seguir será oferecida a evolução histórica e cronológica da legislação localizada e estudada. O "pano de fundo" é a identificação e apresentação de eventos econômicos, políticos e sociais, ocorridos a partir do início do século XIX, que afetaram essa evolução.

\section{EVOLUÇÃO HISTÓRICA DO ENSINO DA CONTABILIDADE NO BRASIL}

A evolução estudada começou no século XIX, com a instituição formal das Aulas de Comércio e do Instituto Comercial do Rio de Janeiro. No século XX, abrangeu o ensino comercial, os cursos profissionalizantes, a criação do ensino superior e a pós-Graduação Stricto Sensu em Contabilidade. Os marcos significativos do estudo estão na Figura 1

\subsection{Século XIX: as Aulas de Comércio}

As sementes para o ensino comercial e de Contabilidade no Brasil foram lançadas no século XIX, com a vinda da Família Real Portuguesa, em 1808. Até então, a atividade comercial brasileira resumia-se à venda dos bens produzidos ao mercado internacional. 


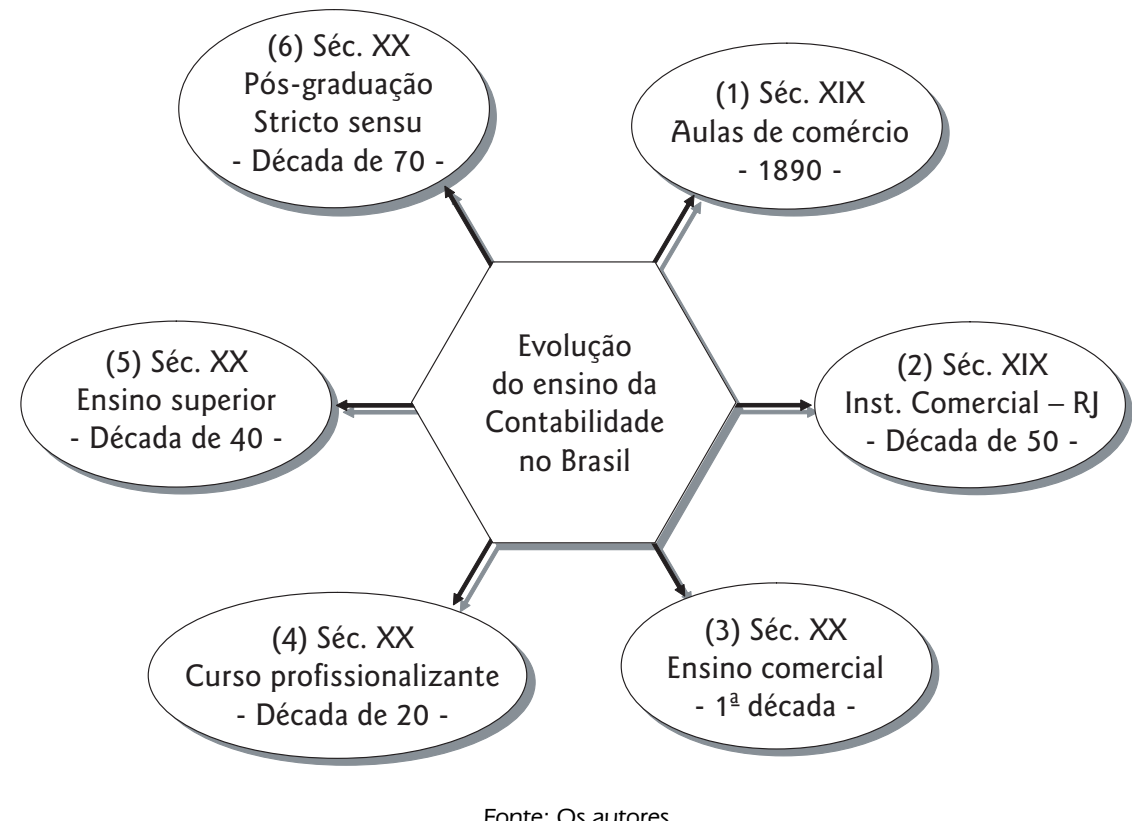

Figura 1 Evolução do ensino da Contabilidade no Brasil

É a exportação desses gêneros [tropicais e metais], pois, que constituirá o elemento essencial das atividades comerciais da colônia. O mais dispor-se-á em torno dela, em dependência direta ou indireta, mas sempre efetiva (PRADO JR., 1998, p. 114).

Internamente, o comércio era composto, em sua maioria, de mercadorias importadas ou destinadas à exportação e, outra parte, ao abastecimento dos grandes centros urbanos. Ao tornar-se sede do Império Português, a situação econômica, política e social da, então, Colônia sofreu grandes alterações. Dentre as mudanças ocorridas, realçou a preocupação do governo com os negócios públicos e privados. Para Furtado (1995, p. 94-5):

Não existindo na Colônia sequer uma classe comerciante de importância [...] resultava que a única classe com expressão era a dos grandes senhores agrícolas. [...] A grande agricultura tinha consciência clara de que Portugal constituía um entreposto oneroso e a voz dominante na época era que a Colônia necessitava urgentemente de liberdade de comércio.

Em 23.11.1808, foi criada uma cadeira de Aula Pública de Ciências Econômicas no Rio de Janeiro, atribuída a José da Silva Lisboa, Visconde de Cairu. Em 1809, foram criadas as Aulas de Comércio, por meio de Alvará de 15 de julho desse ano, iniciando-se o ensino comercial no Brasil. Para Schmidt (2000, p. 205):

Os estudos do comércio tiveram seus passos iniciais na obra de Visconde de Cairu (José Antonio Lisboa) publicada em 1804, intitulada Princípios de Economia Política. Em 1809, ele tornou-se o primeiro a apresentar um sistema de direito comercial e a re- alizar os primeiros estudos de economia política no Brasil.

Apesar da criação da referida cadeira, e de sua atribuição a Cairu, ela não ocorreu de forma pioneira na $1^{\text {a }}$. década do século XIX pois, de acordo com Martins et al. (2006, p. 56):

Os resultados obtidos com esta iniciativa não lograram êxito, sendo que o Visconde de Cairu jamais lecionou uma aula sequer, fato explicado, pois ele não tinha conhecimentos sobre a matéria.

Saes e Cytrynowicz (2001) e Martins et al. (2006) citaram as Aulas de Comércio no Rio de Janeiro e na Província do Maranhão, além de aulas de Ciências Econômicas. Para Saes e Cytrynowics (2006) essas formas de ensino atendiam aos negócios públicos e privados, e foram usadas durante o Império. A menção de Saes e Cytrynowicz e de Silva é confirmada pela pesquisa de Ericeira (2003), que estudou a evolução da Contabilidade no Maranhão vis-à-vis seu desenvolvimento econômico, entre 1755 a 1900.

Ericeira (2003) citou a impossibilidade de haver as $\mathrm{Au}$ las de Comércio antes de 1808 e relatou as condições de realização dessas primeiras Aulas no Maranhão, a partir de 1811, e a suspensão das Aulas pelo Governo Imperial, na década de 1820, pela constatação da incapacidade do professor designado para ministrá-las. As assertivas de Saes e Cytrynowicz e de Ericeira comprovam-se pela análise do Decreto sem número, de 2.08.1831, que restabeleceu a Aula de Comércio na, então, cidade do Maranhão.

A partir da década de 1830, identifica-se, de modo mais claro, o que eram as Aulas de Comércio. Nesse período, o governo imperial, por meio de decretos, aprovou, estabeleceu e modificou as condições de oferta dessas Aulas. 
Durante o século XIX, o comércio com o mercado externo foi o propulsor da economia brasileira, que sofreu rápida e crescente ampliação com a incorporação do desenvolvimento técnico. Um marco relevante, no período, foi a crise do regime escravocrata. O tráfico absorvera até esse século grande parcela de atividades, constituindo o maior negócio brasileiro na época (PRADO JR., 1998, p. 154). A sua proibição, cujo início remonta a 1810, e culmina com a abolição em 1888, quando o soberano português, ao prometer cooperar na campanha inglesa contra o tráfico, desviou recursos para outras atividades produtivas e impulsionou os negócios em diversas áreas.

Prado Jr. (op. cit.) mencionou que o país conheceu, pela primeira vez, um período financeiro áureo de grande movimento de negócios. Além disso, citou diversas iniciativas em empresas comerciais, financeiras e industriais que se sucederam ininterruptamente, o que fez com que todos os índices de atividade subissem de um salto.

Somado ao efeito indireto do incremento das atividades comerciais inglesas, que voltaram ao país após o final do conflito em razão do comércio de escravos, a perda de importância relativa desse comércio até sua extinção teve impacto positivo no desenvolvimento econômico do Brasil no período. Esse foi o cenário para uma maior regulamentação do ensino comercial e da Contabilidade.

Uma preocupação para o Governo Imperial era a lisura usada na escolha e nomeação dos lentes, assim chamados à época os docentes da Aula de Comércio. Em função das irregularidades e da arbitrariedade muitas vezes usada para essa escolha e nomeação, o Governo Imperial definiu, com o Decreto $n^{\circ}$. 121, de 31.01.1842, os critérios para a seleção de docentes. Esse decreto definiu que os indicados seriam avaliados pelo Governo Imperial e que, não existindo substitutos, haveria concurso público para o provimento dos cargos, nas condições ali previstas.

Outro fato relevante foi a promulgação do Regulamento das Aulas de Comércio no Rio de Janeiro, com o Decreto $\mathrm{n}^{\circ} .456$ de 6.07.1846. O período letivo original era de dois anos, com exames finais abordando disciplinas como Direito Comercial, Prática das Principais Operações e Atos Comerciais, e a Arte da Arrumação de Livros, conforme consta no artigo 12 do Regulamento. No capítulo dos objetos do ensino, o Regulamento definia, para o segundo ano, a oferta das disciplinas História Geral do Comércio e Arrumação e Prática de Livros. Os livros deveriam ser escriturados pelos alunos e apresentados quando solicitados.

Os critérios para cursar as Aulas de Comércio eram: ter mais que quatorze anos, obter aprovação no exame da Gramática da Língua Nacional, Aritmética e Língua Inglesa ou Francesa. Os bacharéis em Letras do Colégio Pedro II e os aprovados no primeiro ano da Escola Militar estavam dispensados do exame admissional. As disciplinas eram ministradas por um único professor (lente) a cada ano, admitida a possibilidade de haver um substituto.

A análise do Decreto n ${ }^{\circ}$ 456/46 revela que do currículo da Aula de Comércio possuía disciplinas de cunho prático, voltadas às necessidades diárias dos negócios. Essas atividades requeriam instrumentos de gestão mais precisos, existentes na Contabilidade da época.

\subsection{Século XIX: o Instituto Comercial do Rio de Janeiro}

A década de 50 do século XIX foi palco de outros eventos importantes para o ensino comercial e contábil brasileiro. Ocorreu a reforma da Aula de Comércio da capital imperial, com o Decreto $n^{\circ} .769$, de 9.08.1854. Essa reforma materializou-se com o Decreto $\mathrm{n}^{\circ}$. 1763, de 14.05.1856, que deu novos estatutos à Aula de Comércio da Corte, formando um curso de estudos denominado Instituto Comercial do Rio de Janeiro. Grandes mudanças ocorreram na grade curricular, mantendo-se a duração do curso em dois anos. O conteúdo foi distribuído em quatro cadeiras, sendo a primeira de Contabilidade e Escrituração Mercantil. A comparação desses Estatutos com o Regulamento contido no Decreto $n^{\circ}$. 456/1846 revela a profundidade das mudanças promovidas na Aula de Comércio.

Outro fato importante na época, destacado por Bielinski (2000) e Saes e Cytrynowicz (2001, p.40) era que, apesar de já existirem há cerca de meio século, as aulas de Comércio não atraíam grande número de alunos. Outros cursos, como Direito, Engenharia e Medicina, atraíam número maior de interessados das classes socialmente mais favorecidas na época. A percepção de Bielinski e de Saes e Cytrinowicz confirma-se pelas assertivas de Leite (2005), já mencionadas. Aqui é possível levantar uma hipótese sobre a razão pela qual historicamente os cursos de Ciências Contábeis não despertam grande apelo aos ingressantes, em comparação com outros cursos superiores.

Em meados do século XIX, principalmente pela substituição do trabalho escravo, o centro econômico do país começou a migrar para a Região Sudeste. A produção do café expandiu-se decisivamente, tornando-o o principal produto da pauta de exportações em torno da década de 40 daquele século. Importante nesse processo, segundo Furtado (1995, p.114), é observar que

[a] etapa da gestação da economia cafeeira é também a de formação de uma nova classe empresária que desempenhará papel fundamental no desenvolvimento subseqüente do país.

Além da cultura cafeeira, o surgimento do Código Comercial, em $1850^{2}$, a expansão das estradas de ferro, das empresas de serviços urbanos e dos investimentos estrangeiros foram indicadores de crescimento da eco-

\footnotetext{
2 Os interessados em conhecer melhor as condições que cercaram a promulgação do Código Comercial brasileiro e uma parcela significativa do desenvolvimento econômico havido no século XIX, podem assistir ao filme "Mauá - o Imperador e o Rei”, estrelado por Paulo Betti, no papel de Irineu Evangelista de Souza, o Barão e posteriormente Visconde de Mauá. Outras informações sobre a importância da Contabilidade na vida de Irineu Evangelista de Souza podem ser encontradas nas páginas 139 e 140 do trabalho de Cosenza e no livro de Caldeira, citados nas referências bibliográficas.
} 
nomia. Outro evento importante foi a promulgação da Lei $\mathrm{n}^{\circ}$. 1083, de 22.08.1860, considerada por ludícibus e Ricardino Filho (2002) como a primeira Lei das Sociedades Anônimas do Brasil. Esse quadro contribuiu para uma reorganização do ensino comercial, na década de 60 do século XIX.

O Decreto $n^{\circ}$. 2741, de 9.02.1861, definiu que os estudos do Instituto Comercial do Rio de Janeiro formariam um curso preparatório e outro profissional. Verifica-se, em seu artigo $1^{\circ}$., que o curso profissional possuía quatro cadeiras, sendo a segunda de Escrituração Mercantil e Legislação de Fazenda. No artigo $10^{\circ}$., consta que, para todas as aulas oferecidas no curso profissional, não seria exigida habilitação anterior, exceto para a de Escrituração Mercantil, cuja matrícula dependia de aprovação na cadeira de Aritmética Completa, a primeira oferecida.

Saes e Cytrynowicz (2001, p.41) mencionam que o governo Imperial identificou a necessidade de maior atenção à gestão dos negócios. Isso se traduziu na promulgação do Decreto $n^{\circ} .3058$, de 11.03.1863, que reorganizou o ensino comercial e definiu novos Estatutos para o Instituto Comercial do Rio de Janeiro. A duração do curso passou de dois para quatro anos, permitindo-se a admissão de maiores de treze anos de idade, aprovados em exame de Gramática Nacional e Caligrafia. As disciplinas do curso foram distribuídas nos quatro anos e a disciplina Escrituração Mercantil passou a ser oferecida no $3^{\circ}$. e $4^{\circ}$. anos.

A análise dos critérios de seleção estabelecidos para ingresso nos referidos cursos e da composição da grade curricular, com três disciplinas de línguas estrangeiras (Inglês, Francês e Alemão), e quatro disciplinas da área de Exatas (Aritmética, Álgebra, Geometria e Estatística Comercial), constantes do Decreto $n^{\circ}$. 3058/1863, permitem avaliar o rigor e a qualidade pretendida com o curso oferecido.

Novas mudanças ocorreriam no curso do Instituto Comercial do Rio de Janeiro entre o final da década de $70 \mathrm{e}$ início da década de 80 do século XIX. O Decreto $n^{\circ} .7538$, de 15.11.1879 extinguiu as cadeiras de Francês, Inglês, Alemão, Caligrafia e Matemáticas, e os cargos de Diretor, Secretário e Porteiro.

Os estatutos do Instituto Comercial foram novamente mudados pelo Decreto $n^{\circ}$. 7679, de 28.02.1880. A duração passou para dois anos. As disciplinas extintas pelo Decreto $n^{\circ}$. 7538/1879 tornaram-se pré-requisitos para a seleção, mantendo-se a oferta de Escrituração Mercantil. Apesar da aparente redução do curso, é possível considerar a hipótese de que o nível de exigência para ingresso tenha se mantido ou mesmo aumentado, em função dos pré-requisitos estabelecidos, pois os conhecimentos exigidos eram parte das disciplinas componentes dos dois primeiros anos até então oferecidos.

Bielinski (2000) relatou a extinção do Instituto Comercial do Rio de Janeiro, em 1882. Além da pouca atratividade em relação a outros cursos, a autora descreveu as dificuldades dos alunos em atenderem as exigências para ingresso no curso, e a dificuldade do Instituto em atender as necessidades que o comércio da então Capi- tal Federal apresentava à época. A autora, assim como Rodrigues (1984), citou a criação de outro Instituto Comercial do Rio de Janeiro, por meio do Decreto Legislativo $n^{\circ}$. 98, de 26 de julho de 1894. Relatou que, na mesma época, houve a iniciativa e os esforços para a criação do curso Comercial do Imperial Liceu de Artes e Ofícios do Rio de Janeiro, e os bons resultados obtidos com essa iniciativa.

Após esse período, iniciou-se uma nova fase para o ensino, com grandes mudanças e a expansão do ensino comercial, entre 1889 e 1931. Essas mudanças foram motivadas por uma combinação de fatores: crescimento econômico causado pelo aumento na produção e crescimento da urbanização, principalmente da cidade de São Paulo.

Ainda dominando a pauta de exportações e a economia nacional, como padrão para um modelo agrário-exportador, as flutuações do preço internacional do café afetavam a economia do país. Os períodos de grave crise no setor cafeeiro, ao final do século XIX e início do século XX, causados pela superprodução e pela queda da demanda entre as Grandes Guerras, levaram os produtores de café a investir em outras áreas. O fluxo de capital para esses novos negócios foi significativo, impulsionando-os de maneira decisiva. Para Tavares (1975, p.60):

Assim, dentro do próprio modelo primário-exportador, teve lugar um vigoroso processo de urbanização acompanhado da implantação de uma infra-estrutura de serviços básicos e do desenvolvimento de uma serie de indústrias 'tradicionais'.

No mesmo período cresceram os serviços públicos, por meio dos órgãos administrativos e do aumento da burocracia, o que exigiu maior qualificação dos funcionários para executar suas funções. Para Furtado (1995, p. 71):

As necessidades de ação administrativa no campo dos serviços públicos, da educação e da saúde, da formação profissional, da organização bancária, etc., no sul do país são cada vez maiores. [...] A proclamação da República em 1889 toma, em conseqüência, a forma de um movimento de reivindicação da autonomia regional. Aos novos governos estaduais coubera, nos dois primeiros decênios da vida republicana, um papel fundamental no campo da política econômico-financeira [...] A transiç̧ão de uma prolongada etapa de crédito excessivamente difícil para outra de extrema facilidade deu lugar a uma febril atividade econômica como jamais se conhecera no país.

Furtado (1995, p.172) cita o surgimento de novos grupos de pressão política:

Entre estes se destacam a classe média urbana - empregados do governo, civis e militares, e do comércio - os assalariados urbanos e rurais, os produtores agrícolas ligados ao mercado interno, as empresas estrangeiras que exploram serviços públicos, das quais nem todas têm garantia de juros. 


\subsection{Século XX: O Ensino Comercial e os Cursos Profissionalizantes}

Saes e Cytrynowicz (2001) apontaram grandes mudanças no ensino comercial brasileiro a partir da Proclamação da República, e iniciaram mencionando a extinção do Instituto Comercial do Rio de Janeiro ${ }^{3}$, substituído pela Academia de Comércio do Rio de Janeiro. Por meio do Decreto $n^{\circ}$. 1339, de 9.01.1905, essa Academia foi declarada de utilidade pública e seus diplomas oficialmente reconhecidos. Os títulos dos diplomas concedidos abrangiam dois níveis, já que a Academia possuía dois cursos:

- um de formação geral e prático, que habilitava para as funções de guarda-livros, perito judicial e empregos da área da Fazenda. Esse curso possuía diversas disciplinas, de formação geral e comercial, inclusive Escrituração Mercantil;

- outro de nível superior, cujo ingresso considerava o curso geral como preparatório, habilitava os candidatos para os cargos de agentes-consultores, funcionários dos Ministérios das Relações Exteriores, atuários das seguradoras, chefes de contabilidade de Bancos e de grandes empresas comerciais. Esse curso possuía disciplinas voltadas à formação comercial, além das específicas de Contabilidade do Estado e Contabilidade Mercantil Comparada.

O Decreto n. 1339/05 estendeu suas disposições à Escola Prática de Comércio de São Paulo e à extinta Academia de Comércio de Juiz de Fora. A Escola Prática de Comércio, fundada em 1902, posteriormente denominada Fundação Escola de Comércio Álvares Penteado, tornou-se uma referência no ensino comercial, ao lado da Academia de Comércio do Rio de Janeiro.

Uma prova da importância da Academia de Comércio do Rio de Janeiro foi a edição do Decreto $n^{\circ}$. $4724 A$, de 23.08.1923, que equiparou os diplomas expedidos pela Academia de Ciências Comerciais de Alagoas e de outras instituições de ensino comercial brasileiras aos expedidos da instituição carioca. A relação das instituições que tiveram seus diplomas equiparados está no art. $1^{\circ}$. do referido decreto.

Os cursos profissionalizantes, ou de Ensino Técnico Comercial, foram instituídos pelo Decreto $\mathrm{n}^{\circ}$. 17329, de 28.05.1926, que aprovou o regulamento dos estabelecimentos de ensino para oferecerem esses cursos: um com formação geral de quatro anos e outro, superior, de três anos. O curso geral conferia o diploma de Contador e o superior o título de graduado em Ciências Econômicas. Para ingresso no curso geral, a idade mínima era de treze anos e, no curso superior, dezessete anos. Esse Decreto estabeleceu as disciplinas oferecidas para ambos os cursos, especificadas para cada ano de sua duração. A análise da grade do curso de formação geral revela a oferta das disciplinas Contabilidade, Contabilidade Mercantil, Contabilidade Agrícola e Industrial e Contabilidade Pública.

O Decreto $n^{\circ}$. 20158, de 30.06.1931, regulamentou a profissão de contador e reorganizou o ensino comercial, dividindo-o nos níveis propedêutico, técnico e superior. O propedêutico exigia o mínimo de doze anos para ingresso e realização de exames admissionais. No técnico, dividiu o ensino comercial em ramificações: secretário, guarda-livros e administrador-vendedor, com duração de dois anos, e atuário e perito contador, com duração de três anos. A análise da grade curricular revela a oferta de disciplinas contábeis aplicadas aos negócios mercantis, industriais, agrícolas e bancários.

As mudanças no País eram intensas. Furtado (1995, p.197-198) cita que:

A precária situação da economia cafeeira nas primeiras décadas do século XX afugentava desse setor os capitais que nele ainda se formavam. [...] Restringida a reposição, parte dos capitais que haviam sido imobilizados em plantações de café foram desinvestidos, e foram absorvidos por outros setores da economia, como o sistema comercial, de serviços e o bancário, e ainda mais pelo nascente sistema industrial. [...] o fator dinâmico principal, nos anos que se seguem à crise (de 29), passa a ser, sem nenhuma duvida, o mercado interno. O país passa por um período de inflexão de sua matriz produtiva, deixando de ser unicamente produtor agrícola para se industrializar. Esta mudança impunha ao país a modernização de seus serviços e a adequação de sua mão-de-obra, especializando-a.

O Decreto-lei nº.1535, de 23.08.1939, mudou a denominação do Curso de Perito Contador para Curso de Contador. Ao encerrar as mudanças nos cursos profissionalizantes, o Decreto-lei no. 6141, de 28.12.1943, estabeleceu as bases de organização e de regime do ensino comercial, desdobrando-o em dois ciclos: o primeiro com um curso comercial básico e um segundo com cinco cursos de formação, denominados cursos comerciais técnicos, dentre eles o de Contabilidade. Na mesma data, o Decreto $n^{\circ}$. 14373 regulamentou a estrutura dos cursos de formação do ensino comercial.

\subsection{Século XX: O Ensino Superior em Ciências Contábeis: a Graduação}

Para Vianna e Villela (2005, p.41), o principal legado do período pós-Guerra, até a ascensão de JK, "[...] parece residir no reforço da industrialização baseada na substituição de importações e na continuidade do nacionalismo de cunho pragmático". A vitória do "nacional-estatismo", personalizado durante anos nas figuras de Getúlio Vargas

3 Saes e Cytrynowicz (2001) apontaram 1902 como ano de extinção do Instituto Comercial do Rio de Janeiro, sem especificar a qual instituição se referiam: a criada pelo Decreto no. 1763, de 14.05.1856, ou a criada pelo Decreto Legislativo no. 98, de 23.07.1894. Rodrigues (1984) e Bielinski (2000) informaram a promulgação do Decreto no. 832, de 7.05.1902 como ato de extinção do Instituto Comercial. O relato de Bielinski (2000), com base em documentos da época, citados em seu estudo, permite inferir que o Instituto Comercial extinto em 1902 foi aquele criado em 1894 
e de Juscelino Kubitschek, impunha o desenvolvimento das forças produtivas locais em toda sua extensão técnica e administrativa.

É nesse cenário que surge o curso superior de Ciências Contábeis e Atuariais, por meio do Decreto-lei $n^{\circ} .7988$, de 22.09.1945, com duração de quatro anos, concedendo o título de Bacharel em Ciências Contábeis aos seus concluintes. Em sua primeira edição, a grade curricular do curso tinha como disciplinas específicas: Contabilidade Geral, Organização e Contabilidade Industrial e Agrícola, Organização e Contabilidade Bancária, Organização e Contabilidade de Seguros, Contabilidade Pública e Revisões e Perícia Contábil.

$\mathrm{Na}$ esteira da implantação do ensino superior de Contabilidade, o governo do Estado de São Paulo instituiu, com o Decreto-lei n'. 15601/46, a Faculdade de Ciências Econômicas e Administrativas - FCEA, instalada como dependência da Universidade de São Paulo, no mesmo ano.

A criação da FCEA, posteriormente denominada Faculdade de Economia, Administração e Contabilidade - FEA, lançou as bases do primeiro núcleo de pesquisa Contábil no Brasil, com relevantes contribuições para a área. Para ludícibus (2006, p.41):

Entretanto, foi com a fundação da Faculdade de Ciências Econômicas e Administrativas da USP, em 1946, e com a instalação do curso de Ciências Contábeis e Atuariais, que o Brasil ganhou o primeiro núcleo efetivo, embora modesto, de pesquisa contábil nos moldes norte-americanos, isto é, com professores dedicandose em tempo integral ao ensino e à pesquisa, produzindo artigos de maior conteúdo científico e escrevendo teses acadêmicas de alto valor.

Além da contribuição para o ensino e a pesquisa contábil no Brasil, a seguir mais bem detalhadas, a FEA/USP foi pioneira ao instituir, nos anos 1970, a pós-Graduação Stricto Sensu em Controladoria e Contabilidade.

A Lei $n^{\circ} .1401$, de 31.07.1951, desdobrou o curso de Ciências Contábeis e Atuariais nos cursos de Ciências Contábeis e de Ciências Atuariais, e instituiu diplomas distintos para ambos os cursos. Essa lei permitiu, em seu art. $3^{\circ}$., que os cursos fossem concluídos em três anos, desde que as condições de oferta e os horários assim o permitissem. Esse normativo excluiu a disciplina Organização e Contabilidade de Seguros do curso de Ciências Contábeis e manteve as demais disciplinas contábeis determinadas pelo Decreto-lei $n^{\circ}$. 7988/45.

Os anos 1950 e 1960 foram de grande prosperidade da economia mundial. A chamada "Golden Age", época em que ocorreu a reconstrução dos países europeus, em função do pós-Guerra, e a aplicação em larga escala dos preceitos Keynesianos, foi o período de maior crescimento econômico de todo o século (HOBSBAWN, 1994).

Tavares (1975, p.61) aponta as transformações no setor industrial brasileiro:

Os empresários privados revelaram sua vocação industrial ao aproveitarem os anos mais favoráveis do setor externo (1951/52), para importar em grande quantidade equipamentos e investir nos mais variados setores da atividade interna.

A autora (1975, p.103) descreve o progresso econômico ocorrido no período:

em termos setoriais, toda a ênfase foi concentrada no secundário, sobretudo nas indústrias de transformação, e o próprio terciário, que se beneficiou de uma série de investimentos de infra-estrutura, transportes e energia e teve uma taxa de crescimento moderada no pós-guerra, sobretudo em alguns setores de serviços e da Administração Pública, que se apresentam em muitos aspectos obsoletos.

A partir de 1955, com o Plano de Metas de Juscelino Kubitschek, o país atingiu o auge desenvolvimentista, com altas taxas de crescimento do PIB até 1963. Ainda para o período considerado, Villela (2005, p.49-50) aponta maior participação do setor secundário ou industrial em relação ao setor primário da economia, além da crescente participação na produção de bens duráveis e de capital. Os profissionais desses setores encontravam mercado de trabalho bastante favorável. Nesse período de intensas mudanças, foi necessário adequar os perfis profissionais e, conseqüentemente, dos currículos dos cursos superiores.

Grandes mudanças ocorreram no ensino superior nos anos 1960, com reflexos nos cursos de Ciências Contábeis. Essas mudanças foram motivadas pela Lei $n^{\circ}$. 4024, de 20.12.1961, que fixou as Diretrizes e Bases da Educação Nacional e criou o Conselho Federal de Educação (CFE), fixando os currículos mínimos e a duração dos cursos superiores voltados à formação de profissões regulamentadas.

O Parecer CFE nº. 397/62 promoveu uma grande mudança no ensino de Ciências Contábeis, ao dividir esses cursos nos ciclos de formação básica e profissional. As disciplinas contábeis foram concentradas no ciclo de formação profissional, com Contabilidade Geral, Contabilidade Comercial, Contabilidade de Custos e Auditoria e Análise de Balanços. A Resolução CFE sem número, de 8.02.1963, fixou os mínimos de duração do curso de Ciências Contábeis e ratificou o Parecer CFE nº 397/62.

Os anos 1960 e o início dos anos 1970 foram o cenário do Milagre Econômico, e da Ditadura Militar. A partir da metade da década de 1970, sucederam-se as crises econômicas, em razão das constantes altas do preço do petróleo. Os anos 1980 foram considerados a Década Perdida. Não houve, no período mencionado, mudanças no ensino superior de Contabilidade por comando legal.

A década de 1960 foi palco de outra contribuição relevante da FEA/USP para o ensino da Contabilidade no Brasil. ludícibus (2006, p.42-43) relata substanciais mudanças, ocorridas a partir de 1964, por ação do Prof. José da Costa Boucinhas, com a adoção do modelo didático norte-americano, baseado na obra de Finney \& Miller - Introductory Accounting. Essa ação foi a base para o lançamento, em 1971, do livro "Contabilidade Introdutória", com várias 
edições posteriores, e amplamente adotado nos cursos de Ciências Contábeis brasileiros. Essa época foi o cenário de forte influência da escola norte-americana de Contabilidade, em relação à escola européia, até então predominante.

Entretanto, é preciso resgatar o comentário de ludícibus (2006, p.43-44) de que um progresso constante, duradouro, equilibrado e que dependa de algo mais do que meras adaptações do modelo norte-americano somente ocorrerão sob certas circunstâncias: a continuidade do trabalho profundo sobre princípios contábeis por parte das entidades representativas da profissão; que os técnicos de Contabilidade se dirijam em massa para bons cursos de $\mathrm{Ci}$ ências Contábeis, e que as instituições de ensino e pesquisa dediquem mais esforços e fundos à pesquisa contábil.

Em 1985, o controle político volta aos civis. A partir de 1989 retorna a eleição direta para Presidente da República e, em 1994, inicia-se a estabilidade inflacionária, com o Plano Real. É nesse cenário que voltam a ocorrer mudanças no ensino superior de Contabilidade, em especial a partir da década de 1990.

A Resolução CFE $n^{\circ}$. 03, de 3.10.1992, fixou os conteúdos mínimos e a duração dos cursos de Graduação. Para Ciências Contábeis, a duração estabelecida foi de 2.700 horas/aula, integralizadas no máximo em sete e no mínimo em quatro anos para o período diurno e cinco para o noturno. Fixou também normas para que as instituições de ensino superior elaborassem os currículos para o curso de Ciências Contábeis, definindo o perfil do profissional a ser formado.

A Resolução $n^{\circ}$. 03/92 trouxe contribuições para o ensino da Contabilidade no Brasil, ao introduzir várias novidades. $A$ análise de seu teor revela que os currículos plenos foram elaborados para estimular o conhecimento teórico e prático e permitir o competente exercício da profissão, com vistas às atribuições específicas conferidas por meio do diploma, em âmbito nacional. Procurou, ainda, assegurar condições para o exercício profissional com competência e ética perante a sociedade.

Essa Resolução agrupou as disciplinas em três categorias de conhecimentos: Categoria I: conhecimentos de formação geral e de natureza humanística; Categoria II: conhecimentos de formação profissional e Categoria III: conhecimentos ou atividades de formação complementar. As disciplinas contábeis foram concentradas nas categorias II e III. A categoria II reuniu disciplinas contábeis exigidas na formação superior, conhecimentos eletivos a critério das instituições e as "Contabilidades Aplicadas". A categoria III reuniu conhecimentos ou atividades de formação complementar, obrigatórios de formação instrumental e atividades obrigatórias de natureza prática, a critério de cada instituição.

A Lei $n^{\circ} .9394 / 96$ revogou a Lei $n^{\circ}$. 4024/61, definiu as novas Diretrizes e Bases da Educação Nacional e introduziu várias mudanças no ensino superior, tais como: a qualificação docente, produção intelectual, docentes com regime de tempo integral e perfil profissional ligado à formação da cultura regional e nacional.
Na seqüência, foram promulgados o Parecer CNE/CES $n^{\circ} .776 / 97$, com orientações para as diretrizes curriculares dos cursos de Graduação, e o Edital Sesu/MEC nº. 04/97, convocando as instituições a oferecerem propostas de novas diretrizes curriculares para os cursos superiores, cujo trabalho foi realizado por comissões de especialistas indicados pela Sesu/MEC.

A edição do Parecer CES/CNE nº. 146/2002 marca o início da edição de outros normativos, relativos às Diretrizes Curriculares Nacionais para os cursos de Graduação, inclusive Ciências Contábeis. Destacam-se os seguintes objetivos:

Servir de referência para as instituições na organização de seus programas de formação, permitindo flexibilidade e priorização de áreas de conhecimento na construção dos currículos plenos. Devem induzir a criação de diferentes formações e habilitações para cada área do conhecimento, possibilitando ainda definirem múltiplos perfis profissionais, garantindo uma maior diversidade de carreiras, promovendo a integração do ensino de graduação com a pós-graduação, privilegiando, no perfil de seus formandos, as competências intelectuais que reflitam a heterogeneidade das demandas sociais.

O Parecer CNE/CES n. 67/2003 procurou reunir, em documento específico, todas as referências normativas existentes na Câmara de Educação Superior, sobre a concepção e conceituação dos currículos mínimos profissionalizantes, fixados pelo então Conselho Federal de Educação, e das Diretrizes Curriculares Nacionais estabelecidas pelo Conselho Nacional de Educação.

O Parecer CNE/CES n. 108/2003 buscou promover audiências com a sociedade, durante seis meses, para a discussão e avaliação da duração e integralização dos cursos de Bacharelado. A interação com a sociedade resultou no Parecer CNE/CES n ${ }^{\circ}$.289/2003, que buscou elaborar $e$ aprovar as Diretrizes Curriculares Nacionais do Curso de Graduação em Ciências Contábeis, a serem observadas na organização curricular das IES. O Parecer CNE/CES n. 289/2003 manteve os objetivos propostos pelo Parecer CES/CNE n'. 146/2002.

A Resolução CNE/CES $n^{\circ}$. 6, de 10.03.2004, oficializou o Parecer CNE/CES nº. 289/2003, e instituiu as Diretrizes Curriculares Nacionais. Porém, novas mudanças ocorreriam. O Parecer CNE/CES nº. 269/2004 mudou as Diretrizes Curriculares Nacionais a pedido do IBA - Instituto Brasileiro de Atuária, para que se excluísse do texto da Resolução CNE/CES nº. 6/2004 a menção de que o curso de Ciências Contábeis deveria abranger a inserção dos indispensáveis domínios da atividade atuarial. A justificativa do IBA foi a de que a Ciência Contábil não se confunde com a Atuarial, pois ambas possuem fundamentos distintos. Isso levou à promulgação da Resolução CNE/CES n. 10/2004, em 16.12.2004, que cancelou e substituiu a Resolução CNE/CES n. 6/2004. 


\subsection{A pós-Graduação Stricto Sensu em Contabilidade}

Conhecido o cenário econômico, político e social da década de 1960 e a evolução do ensino comercial, profissionalizante, técnico e superior de Graduação em Contabilidade no Brasil, é necessário apresentar aspectos relevantes da pós-Graduação no País e, em especial, na área das Ciências Contábeis.

A discussão formal sobre pós-Graduação, no Brasil, iniciou-se com a Lei no. 4024, de 20.12.1961. Na parte relativa à educação superior, apresenta o Capítulo I, do qual consta o art. 69 que define os cursos que poderão ser ministrados nas instituições de ensino superior. O item a do referido artigo tratou dos cursos de pós-Graduação, que poderiam ser abertos à matrícula de candidatos que tivessem concluído o curso de Graduação e obtido o respectivo diploma.

A abordagem da Lei no. 4024/61 foi genérica e requereu tratamento mais detalhado, com a edição do Parecer CFE no. 977, de 3.12.1965. O estudo desse Parecer revela que o modelo de pós-Graduação sugerido para o Brasil teve por referência o modelo norte-americano, esse baseado no modelo germânico. O Parecer apresentou a distinção entre a pós-Graduação Lato Sensu e a Stricto Sensu (ou Sensu Stricto e Sensu Lato, de acordo com a redação do Parecer).

Outro aspecto a destacar é o de que, para o modelo de pós-Graduação Stricto Sensu proposto, a oferta de tais cursos, destinados à formação de docentes para o curso superior, deveria ocorrer em dois ciclos sucessivos: o master, com prazo mínimo sugerido de um ano, e o doctor, com prazo mínimo sugerido de dois anos. Em ambos, os alunos deveriam participar de um programa de estudos, dentro de determinadas áreas de concentração e serem assistidos e orientados por um diretor de estudos.

Saviani in Bianchetti e Machado (2002, p.135-163) analisou os elementos distintivos dos cursos de pós-Graduação: o ensino como elemento definidor e determinante dos objetivos a atingir no Lato Sensu, sendo a pesquisa uma mediadora necessária para o alcance dos objetivos preconizados nesses cursos. Na pós-Graduação Stricto Sensu, caracterizam-se os programas, cujo elemento definidor é a pesquisa, determinante dos objetivos a alcançar, traduzidos na formação de pesquisadores e de quadros qualificados para a docência. A mediação no Stricto Sensu ocorre por meio do ensino, procurando garantir e dispor requisitos para o desenvolvimento da pesquisa, elemento fundamental da formação pretendida.

A implantação dos primeiros programas Stricto Sensu em Contabilidade no Brasil ocorreu nos anos 1970. O pioneiro foi o Programa de Mestrado da Faculdade de Economia, Administração e Contabilidade da Universidade de São Paulo, em 1970. Na mesma década de 1970 foi criado o Programa de Mestrado em Ciências Contábeis da Fundação Getúlio Vargas, no Rio de Janeiro, que em 1991 foi reestruturado e transferido para a Universidade Estadual do Rio de Janeiro. Em 1978 foi implantado o Programa de Doutorado em Ciências Contábeis na FEA/USP, pioneiro e único com alunos em nosso País, que vem influenciando de maneira decisiva a pesquisa contábil brasileira, pois a maioria absoluta dos doutores em Ciências Contábeis brasileiros é egressa desse Programa. Ainda, em 1978, foi implantado o Programa de Estudos Pós-Graduados em Ciências Contábeis da Pontifícia Universidade Católica de São Paulo, fortemente apoiado por professores da FEA/USP.

Ao longo da década de 1980, não foram implantados novos programas Stricto Sensu em Contabilidade, o que voltaria a ocorrer na década de 1990 e início do século XXI. Algumas razões para a implantação de novos programas são:

- As exigências da Lei no. 9394/96, nos itens II e III do artigo 52, para que pelo menos um terço do corpo docente das instituições de ensino superior, à partir de Centro Universitário, fosse de professores com titulação mínima de Mestrado, e da existência de professores em tempo integral dedicados à docência e à pesquisa;

- O aumento na oferta de cursos superiores no Brasil e dentre esses os de Ciências Contábeis, ocorrida ao longo da década de 1990;

- O aumento no número de professores doutores em Ciências Contábeis ocorrido no período, apesar de o Brasil ainda possuir, à época, apenas um programa de Doutorado na área4;

- A atuação de professores doutores em outras áreas que não em Ciências Contábeis nos programas Stricto Sensu em Contabilidade, o que em parte reduziu a restrição de haver apenas um Doutorado na área no País e contribuiu para minimizar a endogenia do corpo docente desses Programas.

Além da maior oferta de programas Stricto Sensu, ocorreram e vêm ocorrendo mudanças no sistema de avaliação da pós-Graduação brasileira, por meio da atuação da CAPES - Fundação Coordenação de Apoio ao Ensino Superior $^{5}$. Essa ação se materializou na avaliação realizada em 2004, relativa ao triênio 2001-2003, na qual foram descredenciados dois programas de pós-Graduação em Ciências Contábeis: o da Universidade Estadual do Rio de Janeiro - UERJ, e o da Fundação Visconde de Cairu. Após a referida avaliação, o Programa de Mestrado em Ciências Contábeis da UERJ conseguiu seu recredenciamento junto à CAPES.

O Quadro $3 \bigcirc$ lista os programas Stricto Sensu em Contabilidade no Brasil.

\footnotetext{
4 Foi autorizado pela CAPES o Programa Multi-Institicional e Inter-Regional de Doutorado em Contabilidade, do consórcio mantido pela Universidade de Brasília-UnB, Universidade Federal da Paraíba-UFPB, Universidade Federal de Pernambuco-UFPE e Universidade Federal do Rio Grande do Norte-UFRN. Até a conclusão deste trabalho, referido programa ainda aguardava homologação pelo CNE, sem a oferta regular de turmas.

5 Um exemplo de mudança no sistema de avaliação na pós-Graduação Stricto Sensu brasileira foi o Seminário "Avançar para Melhorar”, promovido pela CAPES em Brasília-DF, de 9 a 10.11.2006. O encontro procurou discutir propostas para um avanço na reflexão sobre o crescimento do Sistema Nacional de Pós-Graduação. Todos os programas Stricto Sensu recomendados pela CAPES receberam convite para participar deste evento.
} 


\begin{tabular}{|l|l|l|}
\hline \multicolumn{1}{|c|}{ INSTITUIÇÃo } & \multicolumn{1}{c|}{ CIDADE/UF } \\
$\begin{array}{l}\text { Programa Multi-Institucional e Inter-Regional - UnB/ } \\
\text { UFPB/UFRN/UFPE }\end{array}$ & $\begin{array}{l}\text { Tapitais dos Estados e } \\
\text { Distrito Federal }\end{array}$ & $\begin{array}{l}\text { Mestrado - 1999 } \\
\text { Doutorado - 2006 - aguardando } \\
\text { homologação do CNE }\end{array}$ \\
\hline Universidade Federal do Rio de Janeiro - UFRJ & Rio de Janeiro - RJ & Mestrado - 1999 \\
\hline Universidade do Vale do Rio dos Sinos - UNISINOS & São Leopoldo - RS & Mestrado - 1998 \\
\hline Pontifícia Universidade Católica de São Paulo - PUC/SP & São Paulo - SP & Mestrado - 1978 \\
\hline Universidade Federal do Ceará - UFC & Fortaleza - CE & Mestrado - 2002 \\
\hline Universidade de São Paulo - USP - Capital - SP & São Paulo - SP & $\begin{array}{l}\text { Mestrado - 1970 } \\
\text { Doutorado -1978 }\end{array}$ \\
\hline Centro Universitário Álvares Penteado - FECAP & São Paulo - SP & Mestrado - 1999 \\
\hline $\begin{array}{l}\text { Fund. Inst. Capixaba de Pesq. em Cont. Econ. e Finanças } \\
\text { - FUCAPE }\end{array}$ & Vitória - ES & Mestrado - 2000 \\
\hline Universidade Federal de Santa Catarina - UFSC & Florianópolis - SC & Mestrado - 2003 \\
\hline Universidade Federal do Paraná - UFPR & Curitiba - PR & Mestrado - 2004 \\
\hline Fundação Universidade Regional de Blumenau - FURB & Blumenau - SC & Mestrado - 2005 \\
\hline Universidade de São Paulo - USP - Ribeirão Preto - SP & Ribeirão Preto - SP & Mestrado - 2005 \\
\hline Universidade Estadual do Rio de Janeiro & Rio de Janeiro - RJ & Mestrado - recredenciado em 2006 \\
\hline Universidade Federal de Minas Gerais & Belo Horizonte - MG & Mestrado - 2006 \\
\hline Universidade Federal da Bahia & Salvador - BA & Mestrado - 2006 \\
\hline
\end{tabular}

Fonte: Secretarias dos programas, sites da CAPES e das instituições

Quadro 3 | Programas de pós-Graduação Stricto Sensu em Contabilidade no Brasil

A criação dos programas Stricto Sensu semeou as condições necessárias para uma maior pesquisa e produção científica em Contabilidade no Brasil. O crescimento da produção científica levou a uma maior presença de trabaIhos de pesquisa em Contabilidade em importantes eventos científicos brasileiros e internacionais, além da criação de eventos específicos, como o Congresso USP de Controladoria e Contabilidade. Como uma conseqüência do aumento da produção científica, abriu-se a possibilidade de publicação de trabalhos na área contábil em periódicos classificados na Base Qualis da CAPES, seguida da criação e manutenção de periódicos por alguns programas Stricto Sensu de Contabilidade.

Uma conseqüência relevante foi a criação da ANPCONT - Associação Nacional de Programas de Pós-Graduação em Ciências Contábeis. A ANPCONT foi criada por iniciativa dos coordenadores dos programas recomendados, em reu- nião realizada na cidade de Vitória - ES, no dia 30.01.2006. Ao analisar o art. $4^{\circ}$. de seu estatuto, verifica-se o objetivo da ANPCONT:

A ANPCONT tem por objetivo atuar na área de educação, congregando e representando as instituições brasileiras que mantêm cursos de mestrado e/ou doutorado em Ciências Contábeis.

Outra conseqüência relevante foi a mudança da denominação da até então chamada área de "Administração e Turismo" da CAPES para área de "Administração, Ciências Contábeis e Turismo", em 2007 (CAPES, 2007). Essa alteração reflete o esforço já empreendido pelos pesquisadores contábeis brasileiros. É um marco importante, mas revela maior responsabilidade na continuidade do trabalho que vem sendo desenvolvido pela comunidade científica contábil brasileira.

\section{CONSIDERAÇÕES FINAIS}

A pesquisa buscou identificar, localizar e analisar a legislação nacional sobre o ensino comercial, profissionalizante, técnico e superior de Contabilidade no Brasil, desde o século XIX até a promulgação da Resolução CNE/CES nº. 10/2004. Na pós-Graduação, permitiu, a partir do início da discussão sobre a necessidade de tais cursos no País, apresentar a cronologia, um relato da evolução e o cenário atual dos programas de Mestrado e de Doutorado em Contabilidade no Brasil.

Foi possível identificar como alguns eventos relevantes ocorridos no cenário econômico, político e social afetaram o ensino comercial e de Contabilidade, além de corroborar alguns aspectos identificados por pesquisadores contábeis, e isso ajuda a melhor delinear o cenário do desenvolvimento histórico da Contabilidade no Brasil. Os resultados obtidos sugerem a continuidade das pesquisas.

Novos trabalhos poderão estudar as disciplinas e conteúdos oferecidos, as condições de oferta, promover a identificação e análise de outros eventos econômicos, políticos e sociais, os elementos de integração entre a Contabilidade e outras áreas de conhecimento, além da 
Economia, e a complementação e/ou retificação do quanto já levantado. Também é possível pesquisar especificamente as mudanças ocorridas na década de 90 do século
$X X$, na qual foram promulgados oito normativos sobre as diretrizes curriculares.

\section{Referências Bibliográficas}

APPOLINÁRIO, F.. Dicionário de metodologia científica: um guia para a produção do conhecimento científico. São Paulo: Atlas, 2004.

ASSOCIAÇÃO NACIONAL DOS PROGRAMAS DE PÓS-GRADUAÇÃO EM CIÊNCIAS CONTÁBEIS-ANPCONT. Ata da Assembléia Nacional de Constituição da ANPCONT. Vitória-ES, 2006.

BACCI, J.. Estudo exploratório sobre o desenvolvimento contábil brasileiro: uma contribuição ao registro de sua evolução histórica. 2002. Dissertação (Mestrado em Controladoria e Contabilidade Estratégica). Centro Universitário Álvares Penteado, São Paulo, SP.

BIELINSKI, A. C.. Educação profissional no século XIX. Curso Comercial do Liceu de Artes e Ofícios: um estudo de caso. Disponível em <http:// www.senac.br/informativo/ BTS/263/boltec263e.htm>. Acesso em: 29 de abril de 2007.

BRASIL. Decreto $s / n^{\circ}$., de 2.08.1831. Estabelece uma aula de commercio na cidade do Maranhão. Colecção de Leis do Império do Brasil.

Decreto $n^{0}$. 121, de 31.01.1842. Regula o provimento das cadeiras da aula do commercio. Colecção de Leis do Império do Brasil.

Decreto no. 456, de 6.07.1846. Manda executar o regulamento da aula do commercio da Cidade do Rio de Janeiro. Colecção de Leis do Império do Brasil.

Decreto $n^{0 .}$ 769, de 9.08.1854. Autorisa o governo para reformar a aula do commercio desta Corte, e a elevar até a quantia de vinte mil réis a contribuição dos alunos. Colecção de Leis do Império do Brasil.

Decreto $n^{0 .}$ 1763, de 14.05.1856. Dá novos estatutos à aula do commercio da Côrte. Colecção de Leis do Império do Brasil.

do Brasil.

Decreto $n^{\circ}$ : 2741, de 9.02.1861. Dá nova organisação ao Instituto Commercial do Rio de Janeiro. Colecção de Leis do Império

Decreto $n^{0}$. 3058, de 11.03.1863. Dá novos estatutos ao Instituto Commercial do Rio de Janeiro. Colecção de Leis do Império

do Brasil.

Decreto $n^{\circ}$.7538, de 15.11.1879. Extingue as cadeiras de francez, inglez, allemão, calligraphia e mathematicas e os logares de Director, Secretario e Porteiro do Instituto Commercial. Colecção de Leis do Império do Brasil.

Decreto $n^{\circ} .7679$, de 28.02.1880. Altera os estatutos do Instituto Commercial do Rio de Janeiro, que baixaram com o Decreto $\mathrm{n}^{\circ}$ 3058, de 11.03.1863. Colecção de Leis do Império do Brasil.

Decreto $n^{o}$. 1339, de 9.01.1905. Declara instituições de utilidade pública a Academia de Commercio do Rio de Janeiro, reconhece os diplomas por ella conferidos, como de caracter official; e dá outras providências.

Decreto $n^{\text {o. }}$ 4724A, de 23.08.1923. Equipara os diplomas da Academia de Sciencias Commerciaies de Alagôas e de outras instituições, aos da Academia Commercial do Rio de Janeiro e dá outras providências.

Decreto $n^{\text {o. }}$ 17329, de 28.05.1926. Approva, o regulamento para os estabelecimentos de ensino technico commercial reconhecidos officialmente pelo Governo Federal.

Decreto $n^{0}$.20158, de 30.06.1931. Organiza o ensino comercial, regulamenta a profissão de contador e dá outras providências.

Decreto-lei $n^{\circ}$. 1535, de 23.08.1939. Altera a denominação do Curso de Perito-Contador e dá outras providências.

Decreto-lei $n^{\circ}$.6141, de 28.12.1943. Lei Orgânica do Ensino Comercial.

Decreto $n^{\text {o. }}$ 14373, de 28.12.1943. Regulamento da Estrutura dos Cursos de Formação do Ensino Comercial.

Decreto-lei $n^{0 .}$ 7988, de 22.09.1945. Dispões sobre o ensino superior de Ciências Econômicas e de Ciências Contábeis e Atuariais.

Lei $n^{\text {o. }}$ 1401, de 31.07.1951. Inclui, no curso de Ciências Econômicas, a cadeira de História Econômica Geral e do Brasil, e desdobra o curso de Ciências Contábeis e Atuariais.

Ministério da Educação. Lei n $n^{0}$ 4024, de 20.12.1961. Estabelece as diretrizes e bases da educação nacional.

Ministério da Educação. Parecer CFE nº. 397/62. Divide os cursos de Ciências Econômicas, Ciências Contábeis e Ciências Atuariais nos ciclos básico e de formação profissional. Documenta Rio de Janeiro: Guanabara, no. 11, janeiro-fevereiro/1963.

Ministério da Educação. Resolução CFE s/ no., de 8.02.1963. Fixa os mínimos de conteúdo e duração dos cursos de Ciências Atuariais, Ciências Contábeis e Ciências Econômicas. Passarinho, Yesis Ilícia (org). Resoluções e Portarias do Conselho Federal de Educação -1962/1978. Brasília: DF - CFE - 1979.

Conselho Federal de Educação. Parecer ñ. 977, de 3.12.1965. Definição dos Cursos de Pós-Graduação. Documenta, n. 44, p. 67-86.

Ministério da Educação. Resolução CFE ñ. 3, de 3.10.1992. Fixa os mínimos de conteúdo e duração do curso de graduação em Ciências Contábeis.

Lei no. 9.394, de 20.12.1996. Estabelece as Diretrizes e Bases da Educação Nacional.

Ministério da Educação. Edital SESU n n. 04, de 10.12.1997. Convoca as instituições de ensino superior a apresentar propostas para as diretrizes curriculares dos cursos superiores.

Ministério da Educação. Parecer SESU n $n^{0}$.776, de 3.12.1997. Orientação para as diretrizes curriculares dos cursos de graduação.

Decreto $n^{0}$.3860, de 9.07.2001. Dispõe sobre a organização do ensino superior, a avaliação dos cursos e instituições, e dá outras providências.

Ministério da Educação. Parecer CES/CNE n. 0146/2002. 
Ministério da Educação. Parecer CNE/CES n $n^{\circ}$ 67/2003.

Ministério da Educação. Parecer CNE/CES n $n^{\circ}$ 108/2003.

Ministério da Educação. Parecer CNE/CES n $n^{\circ}$ 0289/2003.

Ministério da Educação. Resolução CNE / CES n n. 6/2004.

Ministério da Educação. Parecer CNE/CES n $n^{0}$.0269/2004.

Ministério da Educação. Resolução CNE/CES n n. 10/2004.

CALDEIRA, J.. Mauá: empresário do império. São Paulo: Cia. das Letras: 1995.

COLIATH, G. C.. Uma contribuição para o ensino de História do Pensamento Contábil nos cursos de graduação em Ciências Contábeis no Brasil. 2003. Dissertação (Mestrado em Ciências Contábeis e Atuariais). Pontifícia Universidade Católica de São Paulo, São Paulo, SP.

COORDENAÇÃO DE APERFEIÇOAMENTO DE PESSOAL DE NÍVEL SUPERIOR - CAPES. Portaria $n^{0 .} 13$, de 22.02.2007. Altera a denominação da área de "Administração e Turismo" para "Administração, Ciências Contábeis e Turismo". Publicada no DOU de 26.02.2007, Secai I, p. 14.

COSENZA, J. P.. A escrituração contábil através dos tempos: uma revisão histórica da contabilidade contemporânea com base na literatura contábil. Dissertação. 1999. (Mestrado em Ciências Contábeis) - Universidade do Estado do Rio de Janeiro, Rio de Janeiro, RJ.'

ERICEIRA, F.J.. O estado da arte da contabilidade no Estado do Maranhão, vis-à-vis seu desenvolvimento econômico. Dissertação. 2003. (Mestrado em Controladoria e Contabilidade). Faculdade de Economia, Administração e Contabilidade da Universidade de São Paulo, São Paulo, SP.

FURTADO, C.. Formação Econômica do Brasil. 25a . ed. São Paulo: Nacional, 1995.

HOBSBAWN, E.. A Era dos Extremos. O Breve Século XX - 1914-1989. São Paulo: Cia. das Letras, 1994.

IUDÍCIBUS, S.; Ricardino Filho, A. A.. A primeira lei das sociedades anônimas no Brasil. Revista Contabilidade e Finanças - USP, São Paulo, n. 29, p.7-25, maio/ago. 2002.

Teoria da Contabilidade. $8^{\mathrm{a}}$. ed. São Paulo: Atlas, 2006.

LAWRENCE, C.. Brazil - education and accountants. The Accounting Review, jul. 1962, vol. 37, issue 3, p.510-514.

LEITE, C. E. B.. A evolução das ciências contábeis no Brasil. Rio de Janeiro: FGV, 2005.

LUNA, S. V.. Planejamento de pesquisa: uma introdução. São Paulo: EDUC, 2002.

MARTINS, E.; SILVA, A. F.; RICARDINO FILHO, A. A.. Escola Politécnica: possivelmente o primeiro curso formal de Contabilidade do Estado de São Paulo. Revista Contabilidade e Finanças - USP, São Paulo, n. 42, p.113-122, set./dez. 2006

MELIS, F.. Storia della ragioneria - contributo alla conoscenza e interpretazione delle fonti piú significative della storia econômica. Itália: Bologna - Dott. Cesare Zuffi - Editore, 1950.

PRADO Jr., C.. História Econômica do Brasil. 43a . ed. São Paulo: Brasiliense, 1998.

RICARDINO FILHO, A.A..Auditoria: Ensino acadêmico x treinamento profissional. Tese. 2002,(Doutorado em Controladoria e Contabilidade). Faculdade de Economia, Administração e Contabilidade da Universidade de São Paulo, São Paulo, SP.

; MARTINS, G. A.. O livro caixa da ordem terceira de São Francisco em Recife e São Paulo (Brasil): séculos XVII e XVIII. Revista Contabilidade e Finanças - USP, São Paulo, n. 33, p.78-89, set./dez. 2003.

; MARTINS, S. T. A.. Governança corporativa: um novo nome para antigas práticas? Revista Contabilidade e Finanças - USP, São Paulo, n. 36, p.50-60, set./dez. 2004.

RODRIGUES, A. A.. Pesquisa sobre a evolução do ensino comercial, contábil, atuarial; administrativo e econômico no Século XIX. Revista Paulista de Contabilidade, n. 467, p. 50-54,1984.

SÁ, A. L. de. História geral e das doutrinas da contabilidade. São Paulo: Atlas, 1997.

SAES, F. A. M.; CYTRYNOWICZ, R.. O ensino comercial na origem dos cursos superiores de economia, contabilidade e administração. São Paulo, Revista Álvares Penteado, v. 3, n. 6, p. 37-59, junho/2001.

SAVIANI, D.. A pós-graduação em educação no Brasil: pensando o problema da orientação. In: BIANCHETTI, L.; MACHADO, A. M. N. (organizadores). A bússola do escrever: desafios e estratégias na orientação de teses e dissertações. Florianópolis: Ed. da UFSC; São Paulo: Cortez, 2002.

SCHMIDT, P.. História do pensamento contábil. Porto Alegre: Bookman, 2000.

SILVA.A. F.. A contabilidade brasileira no século XIX-leis, ensino e literatura. Dissertação. 2005. (Mestrado em Ciências Contábeis e Financeiras). Pontifícia Universidade Católica de São Paulo, SP.

TAVARES, M.C.. Auge e declínio do processo de substituição de importações no Brasil. In: Da substituição de importações ao capitalismo financeiro, Rio de Janeiro: Zahar, 1975.

VIANNA, S. B.; VILLELA, A.. O pós-Guerra (1945-1955). In: Economia Brasileira Contemporânea (1945-2004). Giambiagi, F. et al., Rio de Janeiro: Elsevier, 2005.

VLAEMMINCK, J.-H.. Historia geral y de las doctrinas de la contabilidad. España: Madrid. Editorial E.J.E.S., 1961.

\section{NOTA - Endereço dos autores}

Fundação Escola de Comércio Álvares Penteado

Av. Liberdade, 532 - Liberdade

São Paulo - SP

01502-001 